\title{
Grazing by Antarctic krill Euphausia superba on Phaeocystis antarctica: an immunochemical approach
}

\author{
Karen L. Haberman ${ }^{1, *}$, Robin M. Ross ${ }^{2}$, Langdon B. Quetin ${ }^{2}$, Maria Vernet ${ }^{3}$, \\ Gabrielle A. Nevitt ${ }^{4}$, Wendy Kozlowski ${ }^{3}$ \\ ${ }^{1}$ Department of Biology, Western Oregon University, Monmouth, Oregon 97361, USA \\ ${ }^{2}$ Marine Science Institute, University of California, Santa Barbara, California 93106, USA \\ ${ }^{3}$ Scripps Institution of Oceanography, University of California, San Diego, California 92093, USA \\ ${ }^{4}$ Department of Neurobiology, Physiology and Behavior, University of California, Davis, California 95616, USA
}

\begin{abstract}
An enzyme-linked immunosorbent assay (ELISA) for Phaeocystis antarctica was developed and used to determine the extent of grazing by Euphausia superba on this prymnesiophyte. First, a specific antiserum to $P$. antarctica was produced and tested on phytoplankton cells and extracts. Then, the antiserum was tested on extracts of stomachs from krill fed diets of either Thalassiosira antarctica or $P$. antarctica, and also on mixtures of these extracts. The antiserum response was a logarithmic function of the percentage of the extract mixture that came from $P$. antarctica-fed krill. In the field, the antiserum was tested on krill collected during December 1996 to February 1997 in the Palmer Long-Term Ecological Research study region west of the Antarctic Peninsula. The antiserum response suggested that krill ingested $P$. antarctica at $20 \%$ of the stations tested, most of them in nearshore areas. Krill grazed $P$. antarctica only at stations where concentrations of the marker pigment for $P$. antarctica, 19'-hexanoyloxyfucoxanthin, were above $0.150 \mathrm{ug} \mathrm{l}^{-1}$. At these stations, the percentage of $P$. antarctica in the krill stomach extracts was positively correlated with chlorophyll $a$ concentrations, but negatively correlated with the proportion of $P$. antarctica within the phytoplankton community. Overall, $P$. antarctica appeared to comprise a relatively small proportion of the phytoplankton utilized by krill, both spatially and temporally.
\end{abstract}

KEY WORDS: Antarctic krill · Diet · Euphausia superba · Grazing · Immunoassay · Phaeocystis antarctica $\cdot$ Phytoplankton

\section{INTRODUCTION}

The prymnesiophyte genus Phaeocystis often dominates the phytoplankton community in spring blooms along the ice edge of the Antarctic Peninsula (Bidigare et al. 1996), where Euphausia superba is abundant in shelf waters (Ross et al. 1996). P. antarctica is a potentially important food resource for the Antarctic krill, E. superba, both because it occurs in large blooms in the Antarctic (Fryxell et al. 1988, Bidigare et al. 1996) and because the size range of the colonies is effectively grazed by E. superba (Meyer \& El-Sayed 1983, Ishii et al. 1985, Quetin \& Ross 1985). Utilization

*E-mail: habermk@wou.edu of Phaeocystis spp. as a food resource by zooplankters is variable (reviewed in Davidson \& Marchant 1992, Weisse et al. 1994). Two potential problems are that the gelatinous matrix of the colonies may clog the filtration apparatus of filter-feeding zooplankters (Schnack et al. 1985), and that some zooplankters, e.g. the euphausiid Thysanoessa sp., tend to fragment colonies of Phaeocystis sp. rather than ingest them (Hansen et al. 1994). Although studies have shown that E. superba ingests P. antarctica (Sieburth 1960, Virtue et al. 1993, Haberman 1998), laboratory experiments suggest that $E$. superba grazes on diatoms at higher rates than on P. antarctica (Haberman 1998) and selects diatoms over $P$. antarctica within mixtures (Haberman 1998). 
Evaluating the contribution of Phaeocystis antarctica to the krill's diet requires analysis of Euphausia superba caught in the field. One approach to analyzing the krill's diet has been to examine the its stomach contents with microscopy (Pavlov 1969, Marchant \& Nash 1986, Zhu 1989, Opalinski et al. 1997). However, because E. superba macerates its food prior to ingestion, the stomach primarily contains morphologically indistinct material. Therefore, microscopic analysis of stomach contents is biased toward food items with hard parts, such as diatoms with thick frustules (Hart 1942), and soft-bodied food items such as $P$. antarctica are difficult to identify with simple light microscopy. Also, it is difficult to quantify the contribution of various food items in the diet with microscopy.

Chemical and molecular techniques provide potential alternatives for the classification of food items which cannot be visually identified. One promising molecular technique for the analysis of gut contents is immunochemistry. Although routinely used on insects (Calver 1984, Sunderland et al. 1987, Hagler \& Naranjo 1994), immunochemical techniques are less frequently applied to aquatic organisms. However, immunochemistry has been used successfully to examine predation by the euphausiid Euphausia pacifica on early life stages of anchovy (Theilacker et al. 1993). Also, while most immunochemistry studies have focused on identifying animal prey, Zagursky \& Feller (1988) used immunochemical methods to analyze ingestion of phytoplankton and seagrass by the grass shrimp Palaemonetes pugio.

One limitation of immunochemical methods of gut analysis is that their previous use has been qualitative, i.e. results indicate only the presence or absence of the food item but not its proportion. However, since assays are generally sensitive enough to detect responses even in very small animals, some degree of quantification can be achieved by looking at the percent of animals which have a response to the prey antiserum (Theilacker 1988, Theilacker et al. 1993). Also, there is potentially a quantitative relationship between prey protein and the immunochemical response, even for polyclonal antibodies directed against whole cells (Ohman et al. 1991). Even more promising, Hentschel \& Feller (1990) obtained a significant linear relationship between the immunochemical response of a polyclonal antibody and the weight of the corresponding prey item within shrimp foreguts. Their assay remained reliable even when some digestion of the prey had occurred.

The purpose of this study was to develop a quantitative method to assess grazing by Euphausia superba on Phaeocystis antarctica in the field. An enzyme-linked immunosorbent assay (ELISA) for $P$. antarctica was first developed and tested on E. superba with known feeding histories. Subsequently, this assay was used to assess $P$. antarctica ingestion by krill collected on the shelf west of the Antarctic Peninsula in the austral summer (December 1996 to February 1997). Relative proportions of $P$. antarctica in krill stomachs from these different stations were then compared to concentrations of marker pigments for $P$. antarctica and to total phytoplankton in the water column.

\section{MATERIALS AND METHODS}

Overview. Several steps were required to develop a quantitative immunoassay for Phaeocystis antarctica and test it on field-collected krill: (1) antiserum to $P$. antarctica was produced in rabbits; (2) the antiserum was screened to verify that it contained antibodies specific for $P$. antarctica, with minimum cross-reactivity to other types of phytoplankton; (3) an enzyme-linked immunosorbent assay (ELISA) was developed and tested on phytoplankton extracts and krill with known feeding histories; (4) known mixtures of krill stomach extracts, prepared from krill fed only $P$. antarctica or only Thalassiosira antarctica, were assayed with the ELISA, and a calibration curve was generated from these assays to convert antiserum response values to percentages of stomach extract; (5) once the assay was developed, extracts of stomachs from field-collected krill were tested for antiserum activity. For each station, the relative proportion of Phaeocystis antarctica in the stomach extract was estimated from the standard curve (step 4 above); (6) this value was compared to the distribution and abundance of $P$. antarctica in the water column as determined by HPLC analysis.

Production and collection of antisera. Preparation of Phaeocystis antarctica inoculum: Two strains of $P$. antarctica, one isolated from Palmer Station, Antarctica by D. Karentz (referred to as 'Strain A') and the other isolated from McMurdo Sound by M. Putt (Provasoli-Guillard Center for the Culture of Marine Phytoplankton, CCMP 1374; referred to as 'Strain B') were used to inoculate rabbits. Cultures were grown in $\mathrm{f} / 2$ medium minus silica (Guillard \& Ryther 1962) at 0.5 to $2.0^{\circ} \mathrm{C}$, and illuminated on a variable light cycle which roughly corresponded to seasonal light conditions at $64^{\circ} \mathrm{S}$ latitude. Strain A was used for the initial inoculation and the first booster. Strain B was used for the 2nd booster because we no longer had cultures of Strain A.

Cells and colonies of Phaeocystis antarctica were concentrated by centrifuging at $150 \times g$ for $4 \mathrm{~min}$. The supernatant (primarily seawater) was siphoned off and discarded, and the concentrated material was centrifuged at $9000 \times g$ for two 2 to 3 min periods to separate the $P$. antarctica colony matrix from the embedded cells (Guillard \& Hellebust 1971) and minimize the 
amount of matrix in the inoculum. The supernatant was removed until there was approximately a 50:50 mixture (by volume) of supernatant and cells. The cells were then resuspended and frozen in liquid nitrogen in a cryovial. Just prior to injection into the rabbit, a 1:1 mixture by volume of thawed $P$. antarctica cell concentrate and Freund's Incomplete Adjuvant (FIA, Sigma) was emulsified in a syringe with a wide bore needle.

Preparation of antisera: Two male New Zealand white rabbits were bled prior to inoculation to obtain unimmunized, control serum ('normal serum'). The initial inoculation totaled $1.0 \mathrm{ml}$ of the 1:1 Phaeocystis antarctica:FIA emulsion, administered in multiple subcutaneous injections. Booster injections, identical in volume and delivery, were administered at $1 \mathrm{mo}$ and at approximately $1 \mathrm{yr}$ after the initial inoculation (a $1 \mathrm{yr}$ period between boosters is not required; see Dresser 1986 for appropriate time intervals). Harvesting of serum followed standard procedures (Dresser 1986). Serum was separated from insoluble blood components (Hudson \& Hay 1989) and sterilized by filtration through a $0.2 \mu \mathrm{m}$ cellulose acetate sterile syringe filter (Nalgene) into a sterile plastic centrifuge tube. The complement was deactivated (Hudson \& Hay 1989). A working portion of the serum was stored at $4^{\circ} \mathrm{C}$, while the rest was aliquoted and stored at $-20^{\circ} \mathrm{C}$.

Screening for Phaeocystis antarctica antibodies. Pre- and post-inoculation sera (referred to as 'normal serum' and 'antiserum', respectively) from both rabbits were initially screened for anti-P. antarctica activity with the immunofluorescence technique of Campbell et al. (1983), but substituting Poretics $0.2 \mu \mathrm{m}$ PCTE black filters for the Irgalan-black stained filters. The assay was carried out on filtered phytoplankton cultures. These sera were tested against both strains of $P$. antarctica and the diatom Thalassiosira antarctica to determine the presence of antibodies specific for $P$. antarctica.

Since the antisera bound to Phaeocystis antarctica, they were further tested against whole-cell concentrates from other phytoplankton species with an enzyme-linked immunosorbent assay (ELISA) to determine the extent of cross-reactivity. Species evaluated included three prymnesiophytes: Pavlova gyrans (University of Texas, Strain UTEX LB992), Isochrysis galbana (UTEX LB987), and Emiliana huxleyi (UTEX LB1016), and two Antarctic diatom species, Thalassiosira antarctica and Corethron criophilum, both isolated by K. L. Haberman from waters near Palmer Station, Antarctica. Attachment of cells to 96-well polystyrene plates was promoted by coating individual wells with $0.1 \%$ poly-L-lysine (Sigma) according to manufacturer's instructions. Concentrated phytoplankton (whole cells) was incubated in the coated wells for $1 \mathrm{~h}$ at room temperature, with 10 wells per phytoplankton type. Duplicates of each phytoplankton type were tested against the primary antiserum in 1:10, 1:100 and 1:1000 dilutions in sterile Tris-buffered saline (TBS), and duplicates of the normal serum diluted at 1:10 and 1:100 in TBS. Goat-antirabbit antiserum conjugated with alkaline phosphatase was used as the secondary antibody and the BCIP/NPT substrate (Sigma) created a visible reaction product. Blocking, washing, incubation and reaction steps followed those of Harlow \& Lane (1988) with minor adjustments determined by trial and error. Reaction product color was evaluated qualitatively as 'none', 'light', 'medium' or 'dark' (Table 1). T. antarctica and C. criophilum were several times more concentrated than the prymnesiophytes. No attempt was made to equalize the concentrations for this assay.

Tests of antibody activity in extracts of phytoplankton and krill stomachs. The ELISA method used to screen the antiserum for anti-Phaeocystis antarctica activity and cross-reactivity was further refined into a quantitative assay for measuring anti- $P$. antarctica activity in phytoplankton cultures and extracts from krill stomachs. Antiserum activities in extracts from krill with known feeding histories were then used to estimate the percentage of $P$. antarctica within the stomachs of field-collected krill.

Preparation of extracts: Concentrated phytoplankton cultures stored at $-80^{\circ} \mathrm{C}$, were thawed and macerated with a miniature tissue grinder and centrifuged at $1000 \times g$. The supernatant was used for protein and antibody tests. The 2 Phaeocystis antarctica strains, 2 diatom species (Thalassiosira antarctica and Corethron criophilum) and 1 non-Phaeocystis prymnesiophyte (Pavlova gyrans) were included in the assays.

Krill fed either Phaeocystis antarctica or Thalassiosira antarctica (Haberman 1998) were frozen at $-80^{\circ} \mathrm{C}$ for use as standards in the antibody assays of stomach extracts. Each extract was prepared by homogenizing stomachs dissected from 10 to $25 \mathrm{krill}$

Table 1. Initial ELISA (antiserum, Rabbit \#420) with visual ranking of reaction product for concentrated phytoplankton cells at different dilutions in Tris-buffered saline (TBS). $3=$ dark, $2=$ medium, $1=$ light, $0=$ none. Normal serum from Rabbit \#420 yielded no reaction for any phytoplankton species. nd: no test conducted

\begin{tabular}{|lcccccc|}
\hline Phytoplankton species & \multicolumn{7}{c|}{$\begin{array}{c}\text { Dilution } \\
1: 100\end{array}$} & $1: 1000$ \\
\hline Phaeocystis antarctica B & 3 & 3 & 3 & 3 & 2 & 2 \\
Pavlova gyrans & 0 & 0 & 0 & 0 & 0 & 0 \\
Emiliana huxleyi & 0 & 0 & 0 & 0 & 0 & 0 \\
Isochrysis galbana & 0 & 0 & 0 & 0 & nd & nd \\
Thalassiosira antarctica & 1 & 1 & 0 & 0 & 0 & 0 \\
Corethron criophilum & 1 & 1 & 0 & 0 & 0 & 0 \\
\end{tabular}


(depending upon krill size) in approximately $100 \mu \mathrm{l}$ of deionized water. The stomach extract was frozen until assayed.

Protein determination of extracts: Phytoplankton and krill stomach extracts were assayed for total protein in order to match the total protein for all samples in immunoassays. The Lowry et al. (1951) method was modified for microplates by reducing the reagent volumes while maintaining reagent proportions. Proteins were dissolved in $\mathrm{NaOH}$ prior to the addition of alkaline copper solution (Lowry et al. 1951). Bovine serum albumin (BSA) was used to derive the protein calibration curve, a logarithmic relationship between BSA concentration and absorbance (Peterson 1977). For each phytoplankton or krill stomach extract, two aliquots at each of 3 dilutions were assayed, and protein values calculated with the logarithmic calibration curve. Extracts were then diluted to final protein concentrations of $6.5 \mu \mathrm{g}$ per $30 \mu \mathrm{l}$ of $10 \mathrm{mM}$ Tris-HCl/ $1 \mathrm{mM}$ EDTA extraction buffer (Theilacker et al. 1986) for the ELISA assays.

Table 2. Details of quantitative ELISA for phytoplankton and krill stomach extracts. (a) Binding of extract to nitrocellulose paper in wells. (b) Quantitative ELISA on extracts bound to nitrocellulose paper. BSA = bovine serum albumin; TBS = Tris-buffered saline; $25 \mathrm{mM}, \mathrm{G}-\mathrm{AR}$ = goat-anti-rabbit antibody; $\mathrm{pNPP}=$ $p$-nitrophenyl phosphate liquid substrate (Sigma)

\begin{tabular}{|c|c|c|c|c|}
\hline & Step & $\begin{array}{l}\text { Volume } \\
\left(\mu \text { well }^{-1}\right)\end{array}$ & Procedure or solution & $\begin{array}{l}\text { Time } \\
(\mathrm{min})\end{array}$ \\
\hline \multirow[t]{8}{*}{ (a) } & Incubation & 30 & $\begin{array}{l}\text { Extracts standardized } \\
\text { for protein }\end{array}$ & 30 \\
\hline & Drying & & Drying oven, $54^{\circ} \mathrm{C}$ & 30 \\
\hline & Evaporation & & Refrigerate, $4^{\circ} \mathrm{C}$ in desiccator & Overnight \\
\hline & Aspiration & & $\begin{array}{l}\text { Excess fluid removed } \\
\text { with pipette }\end{array}$ & \\
\hline & Drying & & Drying oven, $54^{\circ} \mathrm{C}$ & 10 \\
\hline & Incubate & 100 & $3 \%$ BSA in DI water & 15 \\
\hline & Incubate & 100 & $\begin{array}{l}\text { TBS (added to above } \\
\text { solution already in wells) }\end{array}$ & 15 \\
\hline & Aspiration & 50 & Fluid removed with pipette & \\
\hline \multirow[t]{7}{*}{ (b) } & Block & 100 & $3 \%$ BSA in TBS & 60 \\
\hline & $\begin{array}{l}\text { Incubation, } \\
\text { primary } \\
\text { antibody }\end{array}$ & 50 & $\begin{array}{l}\text { Primary antiserum } \\
\text { or normal antiserum } \\
\text { ( } 5 \text { wells each) in } 3 \% \\
\text { BSA in TBS, 1:500 dilution }\end{array}$ & \\
\hline & Wash $(\times 3)$ & 300 & TBS & 10 \\
\hline & $\begin{array}{l}\text { Block } \\
\text { Incubation, } \\
\text { secondary } \\
\text { antibody }\end{array}$ & $\begin{array}{r}100 \\
50\end{array}$ & $\begin{array}{l}3 \% \text { BSA in TBS } \\
\text { G-AR conjugated with } \\
\text { alkaline phosphatase } \\
\text { in TBS, 1:10 } 000\end{array}$ & $\begin{array}{l}60 \\
60\end{array}$ \\
\hline & Wash $(\times 3)$ & 300 & TBS & 10 \\
\hline & $\begin{array}{l}\text { Enzyme-sub- } \\
\text { strate reaction }\end{array}$ & 200 & $\begin{array}{l}\text { pNPP in TBS } \\
\text { buffer (Sigma) }\end{array}$ & 60 (in dark) \\
\hline & Stop reaction & 50 & $3 \mathrm{M} \mathrm{NaOH}$ & 1 (agitate) \\
\hline
\end{tabular}

Quantitative ELISA for Phaeocystis antarctica antigens: The 'screening' ELISA was developed into a quantitative assay. The individual wells in microplates were lined with nitrocellulose paper, cut with a sterile hole-punch. Nitrocellulose paper was chosen for its proven ability to bind euphausiid stomach extracts for immunochemistry (Theilacker et al. 1986). Aliquots of $30 \mu \mathrm{l}$ of extract (phytoplankton or krill stomach) standardized for protein content as described previously, were added to individual wells, with 10 replicates per extract. The extract was bound to the nitrocellulose paper with a series of steps (Table 2a).

Of the 10 replicates, 5 each were incubated with $50 \mu \mathrm{l}$ of a 1:500 dilution of either antiserum or normal serum (Table $2 \mathrm{~b}$ ). The normal serum served as a control for non-specific binding. The 1:500 concentration was determined empirically in preliminary tests to maximize the difference between normal serum and antiserum binding. $p$-nitrophenyl phosphate (pNPP) liquid substrate (Sigma) was used to quantify the assay. Details of blocking, incubation, washing and enzyme-substrate reaction are provided in Table 2b. After stopping the pNPP reaction, $180 \mu \mathrm{l}$ from each well was moved to a clean polystyrene microplate (Corning) and absorption values (in relative units of optical density) at $405 \mathrm{~nm}$ were measured with a Molecular Devices UV Max or Spectra Max microplate reader. The net antiserum response was calculated as the mean optical density (OD) of wells with antiserum minus the mean OD of wells with normal serum. Standard errors for the net response were calculated from the standard errors of the antiserum and normal serum responses (Freedman et al. 1991).

Calibration curve for krill stomach contents. One goal of the ELISA assay was to estimate the percent contribution of Phaeocystis antarctica to the total stomach content. Accordingly, a calibration curve was constructed from extracts of stomachs of krill fed either $P$. antarctica or Thalassiosira antarctica in laboratory grazing experiments. These extracts were first standardized for protein concentration by dilution in the extraction buffer, and then mixed together to provide a range of proportions of $P$. antarctica-derived extract within the mixture: 0 , $20,40,60,80$ and $100 \%$. The ELISA was conducted with each of the six proportions treated as a separate extract. 
Assay for Phaeocystis antarctica in the stomachs of field-collected krill. The quantitative ELISA was used to assess the extent of grazing on $P$. antarctica by Antarctic krill in the field. Krill were collected with a $1 \mathrm{~m}$ ring net (mesh size $1000 \mu \mathrm{m}$ ) deployed from a rubber skiff at 2 stations in the Palmer nearshore region during December 1996 (Fig. 1), and with a 2-m Metro net (mesh size approximately $700 \mu \mathrm{m}$ ) at 22 stations within the Palmer Long-Term Ecological Research (LTER) grid west of the Antarctic Peninsula (Waters and Smith 1992) during the January-February 1997 LTER cruise on the MV 'Polar Duke' (Jan 97 LTER cruise). After collection, krill were individually frozen at $-80^{\circ} \mathrm{C}$. Upon analysis (approximately 1 yr after collection), the stomach was removed, and the contents were extracted and assayed as described in the previous section. Percentage of stomach extract derived from $P$. antarctica was estimated from the calibration curve for stomach extracts of krill with known feeding histories.

Comparison of antiserum response with phytoplankton composition and distribution. Water samples for phytoplankton pigment analysis were collected with Niskin bottles (General Oceanics) deployed from a rubber skiff (Palmer area stations) or from the MV 'Polar

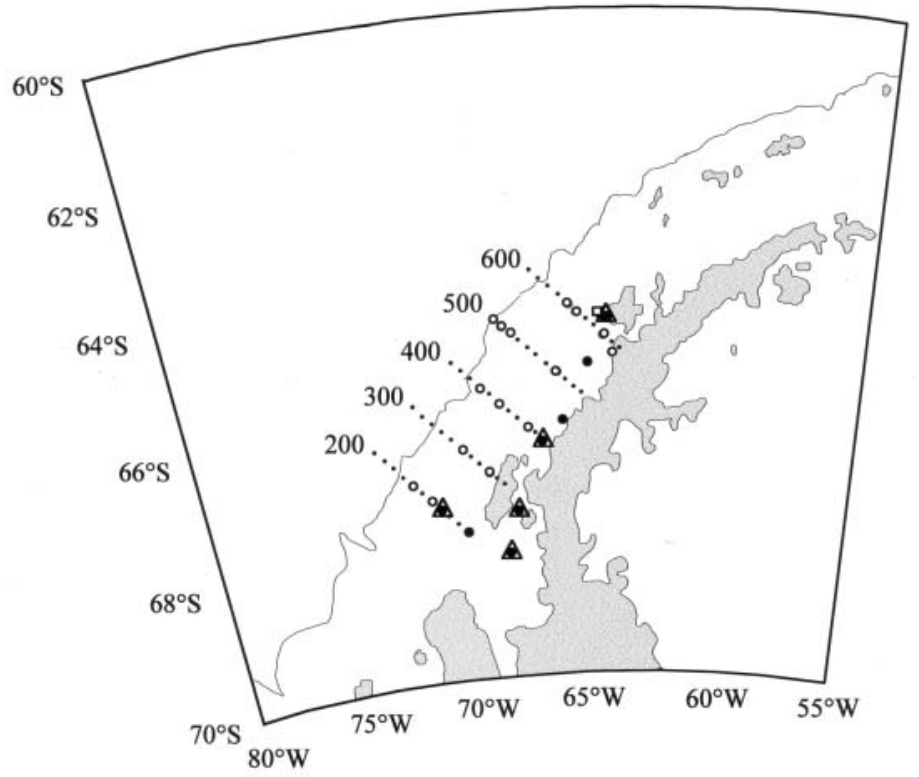

Fig. 1. Palmer Long-Term Ecological Research (LTER) sampling grid west of the Antarctic Peninsula. Transects are $100 \mathrm{~km}$ apart, and stations are $20 \mathrm{~km}$ apart. Circles indicate stations where krill were collected for immunochemistry during the Jan 97 LTER. Small dots are standard grid stations not sampled for this study. The 2 squares are stations sampled in the nearshore region of Palmer during December 1996. Triangles surrounding circles or squares are stations where krill tested positive for grazing on $P$. antarctica. Black circles and gray square: 19'-hexanoyloxyfucoxanthin (HF) levels $>0.150 \mathrm{\mu g} \mathrm{l}^{-1}$; open symbols: HF levels $<0.150 \mu \mathrm{g} \mathrm{l}^{-1}$
Duke' (Jan 97 LTER cruise). Samples were collected at the surface and at depths corresponding to 50, 30, 13, 4 and $0.5 \%$ of photosynthetically available radiation (PAR) measured at the surface. Samples were filtered onto $\mathrm{GF} / \mathrm{F}$ filters and frozen at $-60^{\circ} \mathrm{C}$ for a minimum of $24 \mathrm{~h}$. Pigments were then extracted in $90 \%$ acetone for $24 \mathrm{~h}$ at $-60^{\circ} \mathrm{C}$ and injected onto a Waters C18 $300 \mathrm{~mm}$ column. The solvent protocol was modified from Wright et al. (1991). Peaks were identified by diode array spectrum analysis and integrated using a Hitachi D-7000 system. Concentrations were calculated based on external standard curves. The pigment 19'-hexanoyloxyfucoxanthin (HF) was used to estimate prymnesiophyte (i.e. Phaeocystis antarctica) concentration (Wright et al. 1991). Chlorophyll a (chl a) levels were considered a proxy for total phytoplankton concentration. Only the pigment concentrations at the depth of maximum chl a were compared to the percentage of $P$. antarctica in krill stomachs for each station.

\section{RESULTS}

\section{Screening of antiserum against concentrated phytoplankton}

Preliminary immunofluorescent screening of the antiserum to Phaeocystis antarctica showed a strong fluorescent response primarily associated with the cell surface (not the colony matrix) of $P$. antarctica, and a much weaker response for Thalassiosira antarctica. The strongest responses were obtained for antisera collected after the 2nd booster, so these antisera were used in all subsequent tests. There was a relatively low fluorescent response for the normal serum. Further testing of the antiserum with the initial ELISA technique (BCIP/NBT reaction product evaluated visually, without calibration for protein) showed strong reactivity with $P$. antarctica, minimal cross-reactivity with the diatoms $T$. antarctica and Corethron criophilum and no cross-reactivity with 3 nonPhaeocystis prymnesiophytes: Pavlova gyrans, Isochrysis galbana, and Emiliana huxleyi (Table 1).

\section{Quantitative ELISA for phytoplankton extracts}

The quantitative ELISA demonstrated that the antiserum was specific for Phaeocystis antarctica, with some cross-reactivity for other phytoplankton species. Extracts of the $2 P$. antarctica strains showed highly significant levels of antiserum binding, with optical density (OD) values approximately 7 times those for normal serum (Fig. 2a, $t$-test p < 0.001). Extracts of the prymnesiophyte Pavlova gyrans and the diatom Thalassiosira antarctica also showed significant antiserum binding, but at much 

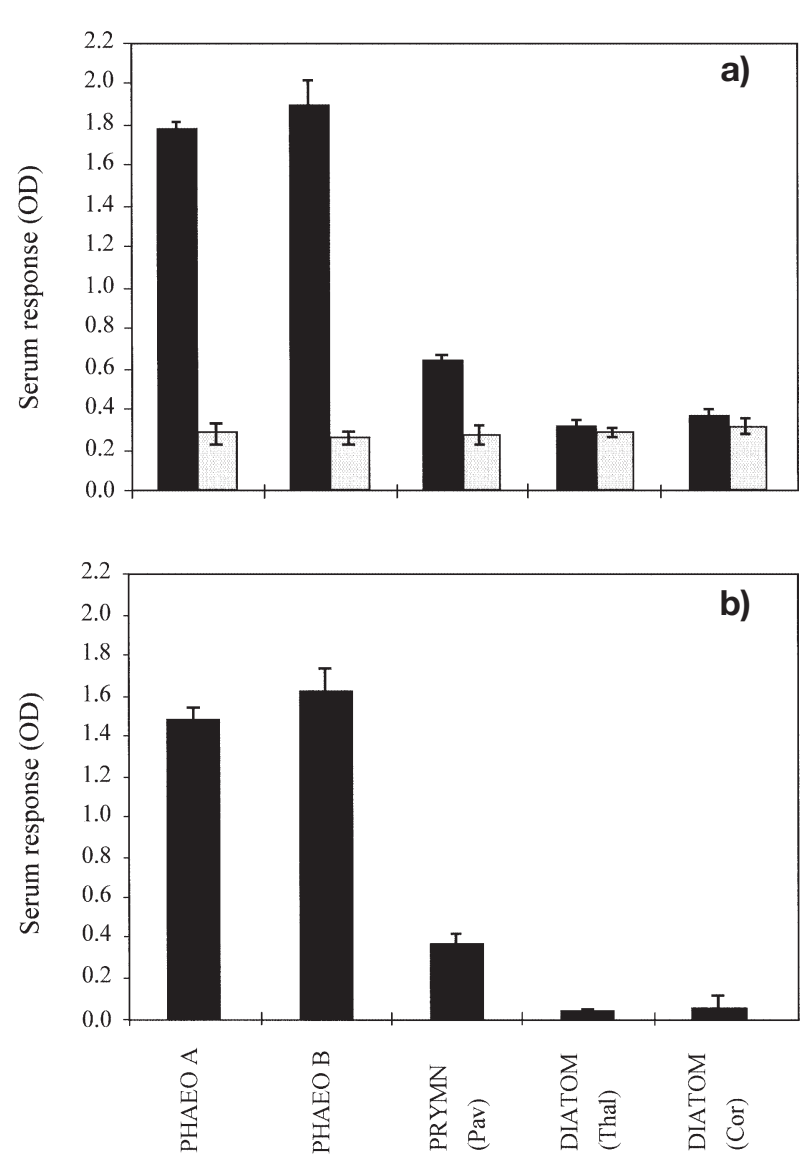

Fig. 2. Quantitative ELISA for phytoplankton extracts. (a) Antiserum (black bar) and normal serum (grey bar) responses. (b) Net antiserum responses. Phaeo A: Phaeocystis antarctica, strain A; Phaeo B: P. antarctica, strain B; Prymn (Pav): Pavlova gyrans; Diatom (Thal): Thalassiosira antarctica; Diatom (Cor): Corethron criophilum. OD = optical density at $405 \mathrm{~nm}$. Error bars are $95 \%$ confidence intervals $(n=5)$

lower levels. OD values for P. gyrans were approximately double those for normal serum ( $\mathrm{p}<0.001)$, with a net antiserum response at $25 \%$ of the $P$. antarctica value (Fig. 2b). OD values for T. antarctica were barely above those for normal serum, with a net antiserum response at only $2 \%$ of the $P$. antarctica values. Corethron criophilum did not show significant antiserum binding.

\section{Quantitative ELISA of Euphausia superba stomach extracts from laboratory grazing experiments}

The OD values for antiserum binding to stomach extracts from krill fed Phaeocystis antarctica in 2 experiments were approximately 4 times the OD values for normal serum (Fig. 3a; $\mathrm{p}<0.001$ ). In contrast, the OD values for antiserum binding for the stomach extract from Euphausia superba fed Thalassiosira antarctica was only 1.3 times the OD value for normal
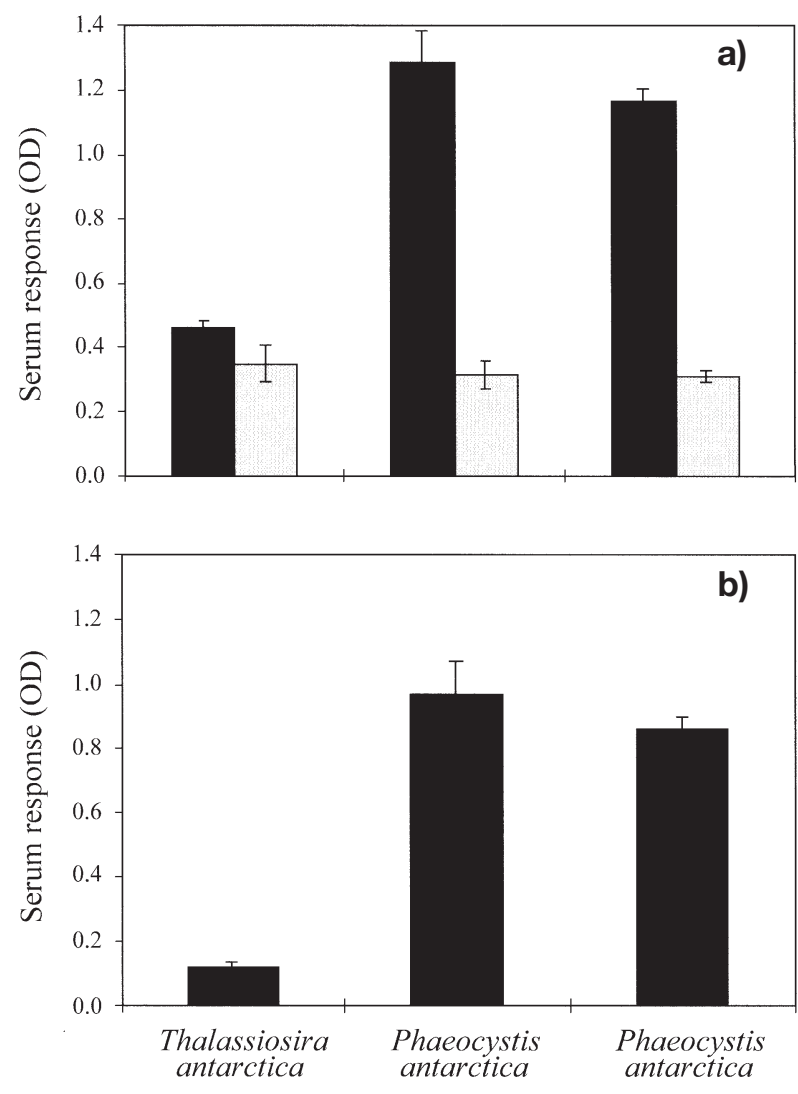

Krill stomach extracts

Fig. 3. Euphausia superba. Quantitative ELISA of stomach extracts for krill fed either Thalassiosira antarctica (1 experiment) or Phaeocystis antarctica (2 experiments). (a) and (b) as in Fig. 2

serum $(p<0.01)$. The net antiserum responses for both experiments with krill fed $P$. antarctica were approximately an order of magnitude greater than the net response for krill fed T. antarctica (Fig. 3b).

The net antiserum responses for mixtures of stomach extracts of krill fed Phaeocystis antarctica or Thalassiosira antarctica were a logarithmic function of the percent $P$. antarctica-fed krill extract in the mixture (Fig. 4). This response curve was used to calculate the percent of $P$. antarctica from the ELISA results for fieldcollected krill. For the curve fit, $0 \%$ P. antarctica was considered as a $1 \%$ response. Stomach extracts with net responses less than, or not significantly different ( $t$-test, $\mathrm{p}<0.05$ ) from this $1 \%$ response $(\mathrm{OD}=0.121$ ) were considered to contain no $P$. antarctica.

\section{Quantitative ELISA for field-collected Euphausia superba}

Positive antiserum responses, indicating Phaeocystis antarctica within krill stomachs, were found in stom- 


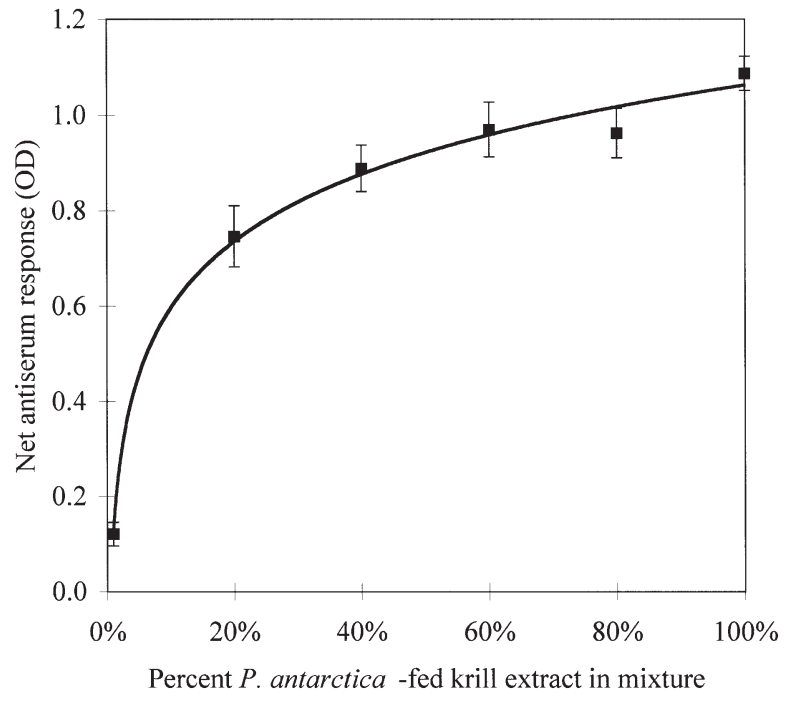

Fig. 4. Euphausia superba. Net antiserum response of mixtures of stomach extract from Phaeocystis antarctica-fed and Thalassiosira antarctica-fed krill. OD = optical density at $405 \mathrm{~nm}$. Error bars are $95 \%$ confidence intervals $(\mathrm{n}=5)$. Curve fit is logarithmic: $y=0.20 \ln (x)+1.06, r^{2}=0.99$

ach extracts from krill collected at 4 of the 22 stations sampled during the Jan 97 LTER cruise (Fig. 1). Estimates for percent $P$. antarctica in stomach extracts ranged from 36 to $100 \%$ (Table 3). Samples from these 4 stations were collected within a $4 \mathrm{~d}$ period, and all were collected in nearshore regions (Table 3 ). In addition, krill from 1 of the 2 Palmer LTER nearshore stations sampled in December, 1996, had a positive, but low $(6 \%)$ response to the antiserum (Fig. 1, Table 3). These results indicated that Euphausia superba grazed $P$. antarctica at approximately $20 \%$ of the stations surveyed.

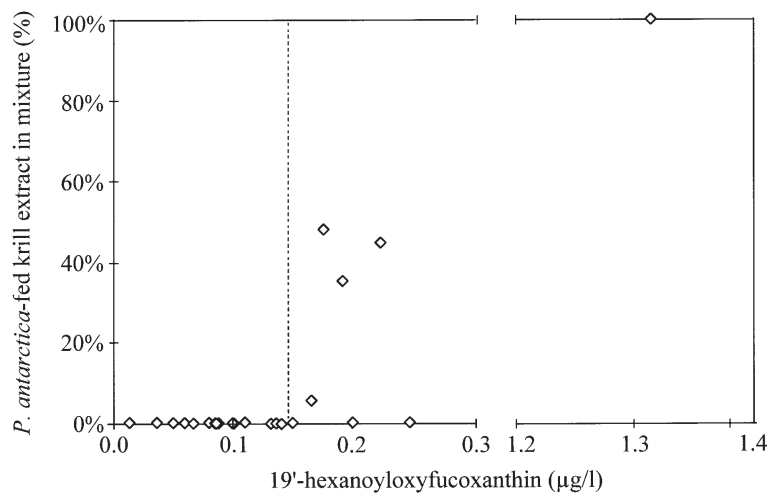

Fig. 5. Proportion (\%) of Phaeocystis antarctica in krill stomach extracts vs concentration of $19^{\prime}$-hexanoyloxyfucoxanthin $\left(\mathrm{HF}, \mu \mathrm{g} \mathrm{l}^{-1}\right)$ in the water column. The dotted vertical line indicates $\mathrm{HF}=0.15 \mu \mathrm{g} \mathrm{l}^{-1}$

\section{Comparison of antiserum response with phytoplankton composition and distribution}

Positive antiserum responses were obtained only in krill from stations where the concentration of $\mathrm{HF}$, the indicator pigment for Phaeocystis antarctica, was above $0.150 \mu \mathrm{g} \mathrm{l}^{-1}$ (Fig. 5). Stations with concentrations above this threshold value were limited to several nearshore stations including the nearshore sector of the $200 \mathrm{~km}$ transect in the most southerly portion of the sampling grid (Fig. 1). Above this HF threshold, the response was variable and the estimated percentage of $P$. antarctica in the krill stomachs was not significantly correlated with HF concentration (Spearman rank correlation, $p>0.05)$. However, in the subset of stations with HF concentrations above the threshold, the percentage of $P$. antarctica in the stomach extracts was positively correlated with chl a concentration (Fig. 6a, Spearman rank correlation, $\mathrm{p}<0.05$ ), and negatively correlated with HF:chl a ratios (Fig. 6b, Spearman rank correlation, $\mathrm{p}<0.05)$. In summary, these results indicate that relatively more $P$. antarctica was ingested at stations with high phytoplankton concentrations and low proportions of $P$. antarctica.

\section{DISCUSSION}

\section{Immunochemical assay methodology}

The quantitative ELISA proved to be a sensitive assay for Phaeocystis antarctica in krill stomach extracts. In the calibration measurements (Fig. 4), a strong, positive response was obtained when only $20 \%$ of the extract was derived from $P$. antarctica-fed krill. In addition, the method did not give false positive responses, i.e. stomach extracts from krill fed Thalassiosira antarctica had a minimal response compared to the stomach extracts from krill fed P. antarctica. Also, there was a dichotomy between the positive and zero responses for field-collected samples, without the intermediate values which would indicate crossreactivity to other food items. The absence of positive responses in krill from stations with HF levels $<0.150 \mu \mathrm{g} \mathrm{l}^{-1}$ also suggests that the antiserum response was specific for $P$. antarctica.

The proportion of Phaeocystis antarctica in krill stomach extracts can be determined to within a few percent for the 15 to $50 \%$ range, where the logarithmic calibration curve is well-defined and steep (Fig. 4). However, the calibration curve is not well-defined for values below $15 \%$, and flattens out for values above $50 \%$, so that estimates are subject to progressively larger errors at either end of the curve. The shape of the curve suggests that the antigen concentrations 

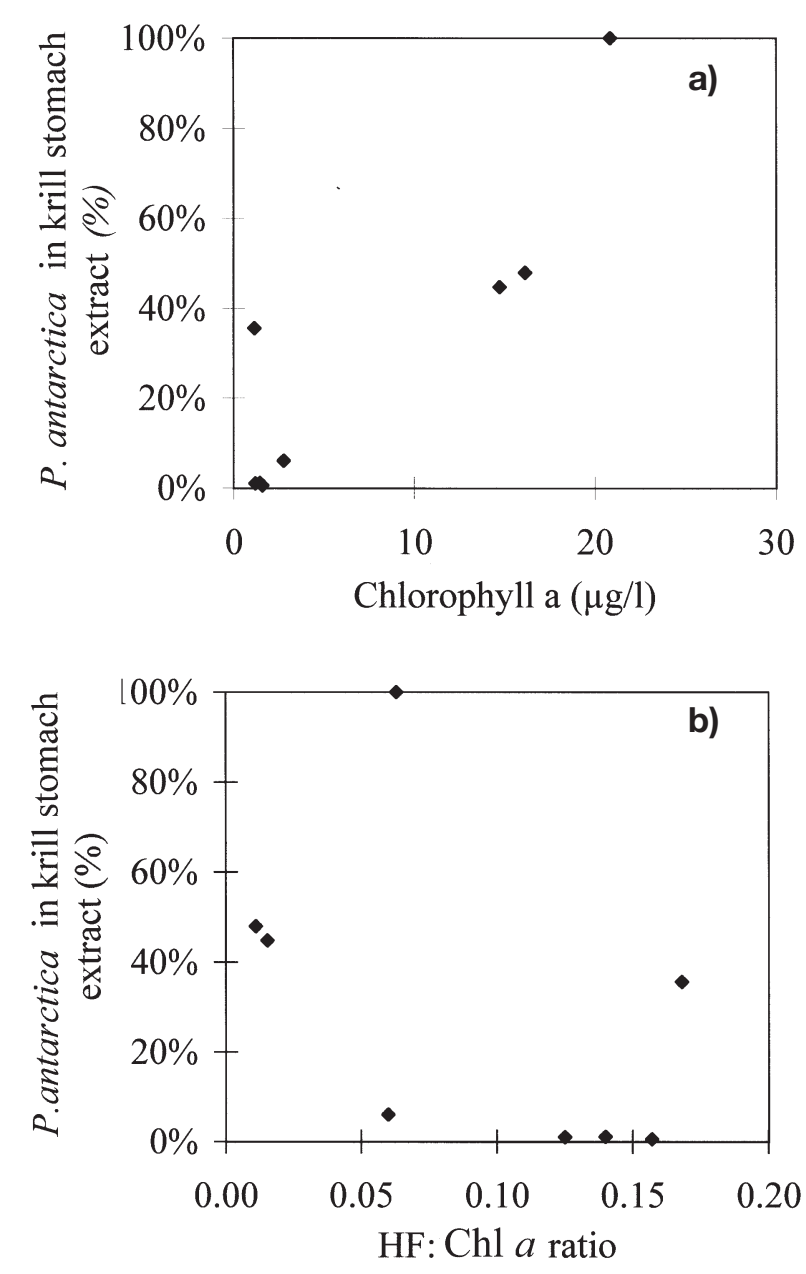

Fig. 6. Proportion (\%) of Phaeocystis antarctica in krill stomach extracts at stations with HF values $>0.15 \mu \mathrm{g} \mathrm{l^{-1 }}$. (a) vs concentration of chlorophyll a (chl $a, \mu \mathrm{g} \mathrm{l}^{-1}$ ) in the water column; (b) vs HF:chl a ratio in the water column

approached saturation for the assay, and future tests should be conducted with more dilute stomach extracts and/or antiserum.

In order to quantify the proportion of extract derived from Phaeocystis antarctica, equal amounts of stomach extract needed to be incubated in and bound to the plate wells. In this study, the amount of stomach extract per well was standardized to protein. Endogenous krill proteins within the stomach, particularly digestive enzymes, could potentially affect the overall food estimation based on protein concentration. However, stomach enzyme levels do not appear to be significantly correlated with stomach protein measurements (Buchholz \& Saborowski 1996). Some of the nonprotein compounds associated with phytoplankton could possibly have affected the protein assays. Nonetheless, such compounds would be similar for all extracts, so the Lowry method still provides a reasonable measure of stomach material.
Since neither the antigen nor the antiserum was purified, the antiserum response must have involved several antigens, epitopes (antigen region which binds to the antibody) and antibodies. In light of this, the antiserum response was remarkably consistent. In particular, replicate wells for field-collected krill had standard errors of less than $5 \%$ of the mean for stations with a positive response to the antiserum (Table 3 ).

While krill in the current study were pooled to assess the variability among replicate plate wells independent of individual feeding variability, future studies will apply the technique to individual animals. ELISA techniques permit assays on very small individuals, such as ladybird beetles (Hagler \& Naranjo 1994) and copepods (Goarant et al. 1994). This should make it possible to calculate the percentage of the krill population which ingested Phaeocystis antarctica, providing another approach to assess the importance of $P$. antarctica in the krill's diet. Theilacker et al. (1993) used this approach to calculate the importance of predation by Euphausia pacifica on larval anchovies off the California coast.

Cross-reactivity potentially limits the usefulness of immunochemical assays for stomach analysis, especially when polyclonal antiserum is used (Feller \& Ferguson 1988, Gallagher et al. 1988). In the quantitative ELISA, significant cross-reactivity of the antiserum occurred for a non-Phaeocystis prymnesiophyte (Pavlova gyrans), but this did not affect the interpretation of results because Phaeocystis is the only prymnesiophyte off the Antarctic Peninsula (Bidigare et al. 1996). The low-level cross-reactivity for diatoms in the initial screening (not in the quantitative ELISA) was probably due to high diatom concentrations. Subsequent protein analysis indicated that diatom levels in these initial assays were at least 10 times higher than those of $P$. antarctica.

Polyclonal antisera are often quite specific. For example, Shapiro et al. (1989) developed non-purified antisera against ultraphytoplankton with specificity at least to the genus level and more often to species level. Similarly, Ohman et al. (1991) tested polyclonal antiserum directed against the ciliate protist Strombidium sp. and found no cross-reactivity to other ciliates, phytoplankton organisms or metazoans. In our study, cross-reactivity with another prymnesiophyte, Pavlova gyrans, may have been enhanced by the use of 2 geographically distinct $P$. antarctica strains for immunization. Use of 2 strains may have increased the number of antibodies produced against epitopes common to both strains, and thus common to prymnesiophytes in general. Similar amplification for antibodies common to cyanobacteria was deliberately obtained when multiple cyanobacteria species were used in an inoculum (Goarant et al. 1994). It is possible that the 2nd booster 
with Strain B increased cross-reactivity since a part of the immune response is likely to have been directed at different moieties than for Strain A. A higher-titered, more specific and less cross-reactive antiserum might have been produced if a mixture of both strains had been injected for all immunizations instead of injecting separate strains at different times.

While cross-reactivity could be a source of falsepositive results, molecular breakdown and a resultant loss of detectability could lead to false-negative results. This is of particular concern for krill compared to other zooplankton. In general, a higher degree of pigment breakdown occurs in larger zooplankters (Nelson 1989). Antarctic krill break down chlorophyll $a$ into non-fluorescing end products at much higher rates than copepods (Perissinotto \& Pakhomov 1996). Similarly, loss of antiserum response may occur as antigen molecules break down within the krill's stomach or during frozen storage, especially since some antibodies require a degree of tertiary molecular structure for epitope recognition (Harlow \& Lane 1988). On the other hand, Hentschel \& Feller (1990) found that changes in antiserum response to oyster protein in the white shrimp foregut were due to actual changes in prey concentration (presumably due to absorption or movement out of the foregut) rather than changes in the antigenic response due to breakdown. Also, it is likely that the anti-Phaeocystis antarctica antibodies were produced against thermally degraded molecules in the first place, since the ambient temperature of $P$. antarctica is 0 to $4^{\circ} \mathrm{C}$, considerably lower than a rabbit's body temperature. In sum, molecular degradation is not expected to be a significant problem for krill stomach immunoassays. Throughput and absorption rates of prey antigen could similarly affect interpretation of results (Hentschel \& Feller 1990) and should be examined in future studies.
Table 3. Euphausia superba feeding on Phaeocystis antarctica. Quantitative ELISA for krill stomach extracts (5 subsamples from pooled extracts of 10 to 25 krill). Positive antiserum responses are underlined. AS: antiserum; NS: normal serum; Phaeo fraction: percentage of extract derived from $P$. antarctica according to calibration curve (Fig. 4). -: values not significantly different from controls; ${ }^{*}$ OD value above, but not significantly different from $100 \%$ calibration value. Sampling stations (Fig. 1): first 3 digits denote transect line (200-600), and second 3 digits denote distance from nearshore, at $20 \mathrm{~km}$ intervals (negative designations: station shoreward of the $0 \mathrm{~km}$ line); $\mathrm{PAL}=$ Palmer nearshore stations

\begin{tabular}{|c|c|c|c|c|c|c|c|c|}
\hline \multicolumn{2}{|c|}{ Station ID } & \multirow{2}{*}{\multicolumn{2}{|c|}{$\begin{array}{c}\text { AS } \\
\text { response } \\
\text { (OD) }\end{array}$}} & \multirow{2}{*}{\multicolumn{2}{|c|}{$\begin{array}{c}\text { NS } \\
\text { response } \\
\text { (OD) }\end{array}$}} & \multirow{2}{*}{\multicolumn{2}{|c|}{$\begin{array}{c}\text { Net AS } \\
\text { response } \\
\text { (OD) }\end{array}$}} & \multirow{3}{*}{$\begin{array}{c}\text { Phaeo } \\
\text { fraction } \\
(\%)\end{array}$} \\
\hline \multirow{2}{*}{$\begin{array}{l}\text { Date } \\
(\mathrm{mo} / \mathrm{d} / \mathrm{yr})\end{array}$} & \multirow{2}{*}{$\begin{array}{c}\text { Grid } \\
\text { location }\end{array}$} & & & & & & & \\
\hline & & Mean & SE & Mean & SE & Mean & SE & \\
\hline $2 / 6 / 97$ & 293. -035 & 1.22 & 0.03 & 0.31 & 0.02 & 0.91 & 0.03 & 48 \\
\hline $2 / 5 / 97$ & $227 .-058$ & $\overline{1.20}$ & $\overline{0.02}$ & $\overline{0.30}$ & $\overline{0.02}$ & $\overline{0.90}$ & $\overline{0.03}$ & $\overline{45}$ \\
\hline $2 / 3 / 97$ & 200.000 & $\overline{0.46}$ & $\overline{0.02}$ & $\overline{0.31}$ & $\overline{0.04}$ & $\overline{0.14}$ & $\overline{0.05}$ & - \\
\hline $2 / 4 / 97$ & 200. -060 & 1.50 & 0.03 & 0.32 & 0.02 & 1.18 & 0.04 & $100^{*}$ \\
\hline $2 / 2 / 97$ & 200.080 & $\overline{0.40}$ & $\overline{0.01}$ & $\overline{0.32}$ & $\overline{0.01}$ & $\overline{0.08}$ & $\overline{0.02}$ & - \\
\hline $2 / 2 / 97$ & 200.120 & 0.36 & 0.01 & 0.31 & 0.02 & 0.05 & 0.02 & - \\
\hline $1 / 30 / 97$ & 300.040 & 0.41 & 0.01 & 0.32 & 0.02 & 0.09 & 0.03 & - \\
\hline $1 / 30 / 97$ & 300.100 & 0.38 & 0.01 & 0.30 & 0.01 & 0.08 & 0.02 & - \\
\hline $2 / 7 / 97$ & 400.000 & 1.21 & 0.03 & 0.35 & 0.03 & 0.85 & 0.04 & $\underline{36}$ \\
\hline $1 / 27 / 97$ & 400.040 & $\overline{0.42}$ & $\overline{0.02}$ & $\overline{0.31}$ & $\overline{0.03}$ & $\overline{0.11}$ & $\overline{0.03}$ & - \\
\hline $1 / 27 / 97$ & 400.100 & 0.36 & 0.02 & 0.34 & 0.01 & 0.02 & 0.03 & - \\
\hline $1 / 28 / 97$ & 400.140 & 0.40 & 0.03 & 0.37 & 0.02 & 0.03 & 0.03 & - \\
\hline $2 / 8 / 97$ & 440.000 & 0.49 & 0.02 & 0.33 & 0.01 & 0.16 & 0.02 & - \\
\hline $1 / 12 / 97$ & 500.060 & 0.36 & 0.01 & 0.29 & 0.01 & 0.08 & 0.01 & - \\
\hline $1 / 13 / 97$ & 500.160 & 0.39 & 0.01 & 0.31 & 0.00 & 0.08 & 0.01 & - \\
\hline 1/13/97 & 500.180 & 0.35 & 0.01 & 0.31 & 0.01 & 0.04 & 0.01 & - \\
\hline $1 / 14 / 97$ & 500.200 & 0.34 & 0.01 & 0.31 & 0.02 & 0.04 & 0.03 & - \\
\hline $2 / 11 / 97$ & 550.030 & 0.34 & 0.01 & 0.33 & 0.01 & 0.01 & 0.02 & - \\
\hline $2 / 12 / 97$ & 596.014 & 0.41 & 0.01 & 0.34 & 0.03 & 0.06 & 0.03 & - \\
\hline $1 / 16 / 97$ & 600.040 & 0.37 & 0.01 & 0.37 & 0.03 & 0.00 & 0.03 & - \\
\hline $1 / 16 / 97$ & 600.100 & 0.32 & 0.01 & 0.35 & 0.02 & -0.03 & 0.02 & - \\
\hline $1 / 17 / 97$ & 600.120 & 0.39 & 0.02 & 0.36 & 0.02 & 0.03 & 0.03 & - \\
\hline $12 / 4 / 96$ & PAL & 0.82 & 0.01 & 0.32 & 0.01 & 0.50 & 0.01 & 6 \\
\hline $12 / 16 / 96$ & PAL & $\overline{0.41}$ & $\overline{0.01}$ & $\overline{0.33}$ & $\overline{0.02}$ & $\overline{0.08}$ & $\overline{0.02}$ & $\overline{-}$ \\
\hline
\end{tabular}

\section{Comparison of antiserum response with phytoplankton composition and distribution}

Results of immunochemical analysis of field-collected krill suggest that grazing by krill on Phaeocystis antarctica was limited in time and space. $P$. antarctica itself was found at relatively low concentrations at most of the stations sampled. We focused on pigment concentrations in the chlorophyll maximum layer because krill are capable of locating concentrated phytoplankton resources (Price 1989). Also, krill schools were generally located at or below the chlorophyll maximum depth during the January-February 1997 LTER cruise.

Sampling at other times and locations will be necessary to assess the contribution of Phaeocystis antarctica to the diet of Euphausia superba at times when and locations where $P$. antarctica is more prevalent. On the other hand, the tendency for krill to ingest a lower proportion of $P$. antarctica when it comprised a higher proportion of total phytoplankton (Fig. 6b) suggests there were relatively low levels of grazing on $P$. antarctica, consistent with laboratory experiments (Haberman 1998). One possibility is that krill did not graze at all at several stations with relatively high proportions of $P$. antarc- 
tica. Perhaps they moved elsewhere to forage, so that grazing per se was low when $P$. antarctica abundance was high. Conversely, at stations where $P$. antarctica was scarce relative to other groups, it was probably ingested as 'by-catch' while the krill targeted the more abundant species. Future studies should couple the immunochemical assays with assessments of overall grazing rates, or some measure of total gut content normalized to krill mass, to investigate these ideas.

We have considered grazing as a function of phytoplankton community composition, but the latter is also affected by grazing. Phytoplankton pigment concentrations in the water column may represent the result of grazing by krill, rather than the community composition available to krill during grazing. Thus, at stations where high percentages of Phaeocystis antarctica in the krill stomachs were correlated with low levels of $P$. antarctica in the water column (Fig. 6b), the P. antarctica may have been low because krill had already grazed it down. Conversely, if krill select other phytoplankters, notably diatoms, in preference to $P$. antarctica, as found in laboratory experiments (Haberman 1998), we would find high proportions of $P$. antarctica in the water column, but little to no P. antarctica in krill stomachs (as in Fig. 6b). Alternatively, the antiserum response may have been secondary, i.e. to $P$. antarctica ingested by small zooplankton subsequently eaten by Antarctic krill. This secondary ingestion is not likely to be high in krill west of the Antarctic Peninsula during the summer, when phytoplankton dominate their diet, but would need to be considered in other seasons and locations.

While gut content information is useful for estimating the proportion of a food item in an animal's diet, measurements of gut contents must be combined with measurements of ingestion rates, as well as rates and efficiencies of assimilation, for accurate assessment. For example, a food item could be found in high proportions in the gut for several reasons, including (1) high overall uptake, (2) high uptake relative to other food sources, and (3) slow digestion. Further laboratory experiments are necessary to help distinguish between possible explanations for low levels of $P$. antarctica within the guts of field-collected krill.

While the immunoassay developed in this study was designed to assess the level of grazing by krill on Phaeocystis antarctica, the technique could be readily adapted for other krill food items. Since antibodies can be produced against plant, protist and animal material, this method could be useful for quantifying the relative levels of herbivory and omnivory in Euphausia super$b a$. This topic has generated much recent interest (Atkinson \& Snÿder 1997, Pakhomov et al. 1997), and is important for clarifying the Antarctic krill's trophic position and winter survival strategies.
Acknowledgements. This research was supported by 3 National Science Foundation grants: OPP90-11927 and OPP96-32763 to the Palmer LTER, and OPP98-14326 to G.A.N. Additional funds were provided by the Office of Research and the Marine Science Institute of the University of California at Santa Barbara. T. Shaw and J. Jones provided exceptional assistance in collecting and processing krill for immunochemical analysis. We thank Captain K. Sanden and the crew of MV 'Polar Duke', as well as the many Antarctic Support Associates at Palmer Station, for their excellent support. This is Palmer LTER Contribution Number 191.

\section{LITERATURE CITED}

Atkinson A, Snÿder A (1997) Krill-copepod interactions at South Georgia, Antarctica, I. Omnivory by Euphausia superba. Mar Ecol Prog Ser 160:63-76

Bidigare RR, Iriarte JL, Kang SH, Karentz D, Ondrusek ME, Fryxell GA (1996) Phytoplankton: quantitative and qualitative assessments. In: Ross RM, Hofmann EE, Quetin LB (eds) Foundations for ecological research west of the Antarctic Peninsula. American Geophysical Union, Washington, DC, p 173-198

Buchholz F, Saborowski R (1996) A field study on the physiology of digestion in the Antarctic krill, Euphausia superba, with special regard to chitinolytic enzymes. J Plankton Res 18:895-906

Calver MC (1984) A review of ecological applications of immunological techniques for diet analysis. Aust J Ecol 9:19-25

Campbell L, Carpenter EJ, Iacono V (1983) Identification and enumeration of marine chroococcoid cyanobacteria by immunofluorescence. Appl Environ Microbiol 46:553-559

Davidson AT, Marchant HJ (1992) The biology and ecology of Phaeocystis (Prymnesiophyceae). Prog Phycol Res 8:1-45

Dresser DW (1986) Immunization of experimental animals. In: Weir DM (ed) Handbook of experimental immunology. Blackwell, Oxford, p 8.1-8.21

Feller RJ, Ferguson RB (1988) Quantifying stomach contents using immunoassays: a critique. In: Yentsch CM, Mague FC, Horan PK (eds) Immunochemical approaches to coastal, estuarine and oceanographic questions. Springer, New York, p 295-303

Freedman D, Pisani R, Purves R, Adhikari A (1991) Statistics. Norton, New York

Fryxell GA, Kendrick GA (1988) Austral spring microalgae across the Weddell Sea ice edge: spatial relationships found along a northward transect during AMERIEZ 83. Deep-Sea Res 35:1-20

Gallagher ED, Jumars PA, Taghon GL (1988) The production of monospecific antisera to soft-bottom benthic taxa. In: Yentsch CM, Mague FC, Horan PK (eds) Immunochemical approaches to coastal, estuarine and oceanographic questions. Springer, New York, p 304-311

Goarant E, Presnier G, Lair N (1994) Specific immunological probes for the identification and tracing of prey in crustacean gut contents. The example of cyanobacteria. Arch Hydrobiol 131:243-252

Guillard RRL, Hellebust JA (1971) Growth and the production of extracellular substances by two strains of Phaeocystis pouchetii. J Phycol 7:330-338

Guillard RRL, Ryther JH (1962) Studies of marine planktonic diatoms I. Cyclotella nana Hustedt and Detonula confervacea (Cleve) Gran. Can J Microbiol 8:229-245

Haberman KL (1998) Feeding ecology of the Antarctic krill, 
Euphausia superba: the role of phytoplankton community composition in the krill's diet. PhD thesis, University of California, Santa Barbara

Hagler JR, Naranjo SE (1994) Qualitative survey of two coleopteran predators of Bemisia tabaci (Homoptera: Aleyrodidae) and Pectinophora gossypiella (Lepidoptera: Gelechiidae) using a multiple prey gut content ELISA. Env Entomol 23:193-197

Hansen B, Verity P, Falkenhaug T, Tande KS, Norrbin F (1994) On the trophic fate of Phaeocystis pouchetii (Harriot). V. Trophic relationships between Phaeocystis and zooplankton: an assessment of methods and size dependence. J Plankton Res 16:487-511

Harlow E, Lane D (1988) Antibodies: a laboratory manual. Cold Spring Harbor Laboratory, New York

Hart TJ (1942) Phytoplankton periodicity in Antarctic surface waters. Discovery Rep 21:261-356

Hentschel BT, Feller RJ (1990) Quantitative immunoassay of the proventricular contents of white shrimp Panaeus setiferus Linnnaeus: a laboratory study. J Exp Mar Biol Ecol 139:85-99

Hudson L, Hay FC (1989) Practical immunology. Blackwell, Oxford

Ishii H, Omori M, Murano M (1985) Feeding behavior of the Antarctic krill E. superba Dana: I. Reaction to size and concentration of food particles. Trans Tokyo Univ Fish $6: 117-124$

Lowry OH, Rosebrough NJ, Farr AL, Randall RJ (1951) Protein measurement with the folin-phenol reagent. J Biol Chem 193:265-275

Marchant HJ, Nash CV (1986) Electron microscopy of gut contents and faeces of Euphausia superba Dana. In: Hoshiai T, Nemoto T, Niato Y (eds) Proc 7th Symp Polar Biol, National Institute of Polar Research, Tokyo, p $167-177$

Meyer MA, El-Sayed SZ (1983) Grazing of Euphausia superba Dana on natural phytoplankton populations. Polar Biol 1:193-197

Nelson JR (1989) Phytoplankton pigments in macrozooplankton feces: variability in carotenoid alterations. Mar Ecol Prog Ser 52:129-144

Ohman MD, Theilacker GH, Kaupp SE (1991) Immunochemical detection of predation on ciliate protists by larvae of the northern anchovy (Engraulis mordax). Biol Bull 181:500-504

Opalinski K, W., Maciejewska K, Georgieva LV (1997) Notes on food selection in the Antarctic krill, Euphausia superba. Polar Biol 17:350-357

Pakhomov EA, Perissinotto R, Froneman PW, Miller DGM (1997) Energetics and feeding dynamics of Euphausia superba in the South Georgia region during the summer of 1994. J Plankton Res 19:399-423

Pavlov VY (1969) The feeding of krill and some features of its behaviour. Trudy VNIRO 66:207-222

Perissinotto R, Pakhomov EA (1996) Gut evacuation rates and pigment destruction in the Antarctic krill Euphausia superba. Mar Biol 125:47-54

Peterson GL (1977) A simplification of the protein assay method of Lowry et al. which is more generally applicable. Anal Biochem 83:346-356

Editorial responsibility: Otto Kinne (Editor), Oldendorf/Luhe, Germany
Price H (1989) Swimming behavior of krill in response to algal patches: A mesocosm study. Limnol Oceanogr 34: 649-659

Quetin LB, Ross RM (1985) Feeding by Antarctic krill, Euphausia superba: does size matter? In: Siegfried WR, Condy PR, Laws RM (eds) Antarctic nutrient cycles and food webs. Springer, Berlin, p 372-377

Ross RM, Quetin LB, Lascara CM (1996) Distribution of Antarctic krill and dominant zooplankton west of the Antarctic Peninsula. In: Ross RM, Hofmann EE, Quetin LB (eds) Foundations for ecological research west of the Antarctic Peninsula. American Geophysical Union, Washington, DC, p 173-198

Schnack SB, Smetacek V, Bodungen v B, Stegmann P (1985) Utilization of phytoplankton by copepods in Antarctic waters during spring. In: Gray JS, Schristiansen ME (eds) 18th Eur Mar Biol Symp, Oslo, 14-20 Aug 1983. Wiley, Chichester, p 65-79

Shapiro LP, Campbell L, Haugen EM (1989) Immunochemical recognition of phytoplankton species. Mar Ecol Prog Ser $57: 219-224$

Sieburth JM (1960) Acrylic acid, an 'antibiotic' principle in Phaeocystis in Antarctic waters. Science 132:676-677

Sunderland CL, Gillett SM, Morrissey SM, Ramsdell DC (1987) A study of feeding by polyphagous predators on cereal aphids using ELISA and gut dissection. J Appl Ecol 24:907-933

Theilacker GH (1986) Use of an ELISPOT immunoassay to detect euphausiid predation on larval anchovy. Mar Ecol Prog Ser 30:127-131

Theilacker GH (1988) Euphausiid predation on larval anchovy at two contrasting sites off California determined with an ELISPOT immunoassay. In: Yentsch CM, Mague FC, Horan PK (eds) Immunochemical approaches to coastal, estuarine and oceanographic questions. Springer, New York, p 304-311

Theilacker GH, Lo NCH, Townsend AW (1993) An immunochemical approach to quantifying predation by euphausiids on the early stages of anchovy. Mar Ecol Prog Ser 92:35-50

Virtue P, Nichols PD, Nicol S, McMinn A, Sikes EL (1993) The lipid composition of Euphausia superba Dana in relation to the nutritional value of Phaeocystis pouchetii (Hariot) Lagerheim. Antarct Sci 5:169-177

Waters KJ, Smith RC (1992) Palmer LTER: a sampling grid for the Palmer LTER program. Antarct J US 27:236-239

Weisse T, Tande K, Verity P, Hansen F, Gieskes W (1994) The trophic significance of Phaeocystis blooms. J Mar Syst 5:67-79

Wright SW, Jeffrey SW, Mantoura RFC, Llewellyn CA, Bjornland T, Repeta D, Welschmeyer N (1991) Improved HPLC method for the analysis of chlorophylls and carotenoids from marine phytoplankton. Mar Ecol Prog Ser 77: 183-196

Zagursky G, Feller RJ (1988) Application of immunoblotting for dietary analysis. In: Yentsch CM, Mague FC, Horan PK (eds) Immunochemical approaches to coastal, estuarine, and oceanographic questions. Springer, New York, p $117-129$

Zhu G (1989) Diet analysis of Antarctic krill, Euphausia superba Dana. Oceanol Sin 8:457-462 (English edition)

Submitted: August 26, 1999; Accepted: June 12, 2002

Proofs received from author(s): August 30, 2002 